Published July 2018

EKONOMIKAWAN : Jurnal Ilmu Ekonomi dan Studi Pembangunan

ISSN : 1693-7600 (Print), ISSN : 2598-0157 (Online), http://jurnal.umsu.ac.Id/index.php/ekawan

\title{
Analisis Penilaian Penerapan Bantuan Alat Tangkap Pada Hasil Tangkap Nelayan Pesisir Desa Pahlawan Kecamatan Tanjung Tiram Kabupten Batu Bara
}

\author{
Dewi Mahrani Rangkuty \\ Fakultas Sosial Sains Universitas Pembangunan Panca Budi \\ Jl. Jend. Gatot Subroto Km. 4,5, Medan 20122 \\ Email :dewimahrani@dosen.pancabudi.ac.id
}

\begin{abstract}
ABSTRAK
Desa Pahlawan adalah salah satu daerah yang memiliki sumber daya alam untuk sektor perikanan di Indonesia. Lokasinya berada di Kecamatan Tanjung Tiram, Kabupaten Batu Bara, Provinsi Sumatra Utara. Berbagai jenis komoditas perikanan diproduksi seperti teri, udang, kerang, dan jenis makanan laut lainnya. Penelitian ini bertujuan untuk menganalisis dampak penangkapan ikan bagi pelaksanaan nelayan di Desa Pahlawan, Kecamatan Tanjung Tiram, Kabupaten Batu Bara. Penelitian khusus untuk menganalisis perbedaan dalam bagaimana sebelum memancing pelaksanaan bantuan dan sesudahnya. Hipotesisnya adalah ada perbedaan yang signifikan antara sebelum memancing menangani implementasi bantuan dan setelah untuk kuantitas produksi. Hasil untuk penelitian ini dengan uji tanda memiliki perbedaan yang signifikan antara sebelum pelaksanaan penanganan penangkapan ikan dan setelah untuk kuantitas produksi. Untuk pemerintah daerah oleh Departemen Kelautan dan Perikanan, Kabupaten Batu Bara, Provinsi Sumatera Utara, dapat dijaga produktivitas nelayan di Desa Pahlawan sebagai kepedulian terhadap kuantitas produksi, karena dapat dipengaruhi oleh stabilitas harga dalam pasar sebagai indikator kesejahteraan bagi para nelayan.
\end{abstract}

Kata kunci: Memancing, Nelayan, Uji Tanda 
Published July 2018

EKONOMIKAWAN : Jurnal Ilmu Ekonomi dan Studi Pembangunan

ISSN : 1693-7600 (Print), ISSN : 2598-0157 (Online), http://jurnal.umsu.ac.Id/index.php/ekawan

\section{Analysis Of Assesment Of Application Of Capture Tools On The Results Of Coastal Fishermen Fisheries Tanjung Tiram District, Batu Bara District}

\section{ABSTRACT}

Desa Pahlawan is one of region has natural resources for fishery sector in Indonesia. The location is in Kecamatan Tanjung Tiram Kabupaten Batu Bara Provinsi Sumatera Utara. Many kind of fishery commodity had produced in there like anchovy, shrimp, shells, and other kind sea food. This research has aim for analyzing the impact for fishing tackle aid implementation for fishermen at Desa Pahlawan Kecamatan Tanjung Tiram Kabupaten Batu Bara. The research speciality has for analyzing difference of how before fishing tackle aid implementation and after. The hypothesis are there significant difference between before fishing tackle aid implementation and after for the quantity of production. The result for this research by sign test has significant difference between before fishing tackle aid implementation and after for the quantity of production. For the local government by Dinas Kelautan dan Perikanan Kabupaten Batu Bara Provinsi Sumatera Utara could be keep the productivity of fishermen at Desa Pahlawan as concern for quantity of production becauce it can be influence for selling price stability in market as welfare indicator for the fishermen.

Keywords : fishing tackle, fishermen, sign test 
Published July 2018

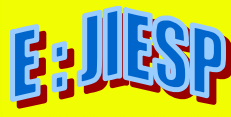

EKONOMIKAWAN : Jurnal Ilmu Ekonomi dan Studi Pembangunan

ISSN : 1693-7600 (Print), ISSN : 2598-0157 (Online), http://jurnal.umsu.ac.ld/index.php/ekawan

\section{PENDAHULUAN}

Desa Pahlawan merupakan salah satu desa yang terdapat di Kecamatan Tanjung Tiram Kabupaten Batu Bara Provinsi Sumatera Utara. Desa Pahlawan terdiri atas 12 Dusun. Lokasi Desa Pahlawan terletak tidak jauh dari daerah pesisir pantai sehingga masyarakat setempat rata-rata bermata pencaharian sebagai nelayan pesisir. Keadaan alam dan geografis yang mendukung menjadikan masyarakat di Desa Pahlawan meningkatkan produktivitasnya dengan menghasilkan hasil tangkap laut dan tambak demi memenuhi kebutuhan ekonomi setiap hari.

Berdasarkan hasil pengamatan awal bahwa mata pencaharian masyarakat di Desa Pahlawan adalah $90 \%$ sebagai nelayan dan penambak ikan dan udang. Faktor yang membuat masyarakat berprofesi sebagai nelayan dikarenakan wilayah Desa Pahlawan dekat dengan Pelabuhan Tanjung Tiram. Mata pencaharian masyarakat di Desa Pahlawan sebagai penambak ikan dan udang juga memiliki faktor dengan wilayah desa itu sendiri. Banyak lahan kosong yang dimanfaatkan masyarakat setempat untuk membuka tambak ikan dan udang dan sebagian masyarakat berprofesi sebagai nelayan juga memanfaatkan sebagai sumber tambahan penghasilan.

Menurut Prakoso (2013) masyarakat nelayan identik dengan kemiskinan, banyak hal yang menyebabkannya yaitu kurangnya modal yang dimiliki para nelayan, teknologi yang dimiliki, rendahnya akses pasar dan rendahnya partisipasi masyarakat dalam pengolahan sumber daya alam. Ada penyebab lain yang non ekonomi atau biasa disebut faktor sosial seperti pertumbuhan jumlah penduduk yang tinggi, rendahnya tingkat pendidikan dan rendahnya tingkat kesehatan serta alasan lain seperti sarana dan prasarana umum di wilayah pesisir. Kurangnya perencanaan spasial yang mengakibatkan tumpang tindihnya beberapa sektor suatu kawasan, polusi dan kerusakan lingkungan.

Pemerintah dalam hal ini Kementrian Kelautan dan Perikanan (KKP) berupaya meningkatkan kesejahteraan nelayan melalui pendapatan nelayan dalam negeri dengan melakukan penerapan pemberian bantuan kepada nelayan yang disebut dengan istilah 'bantuan alat tangkap ikan' (Dirjen Perikanan Tangkap, 2016). Melalui Dinas Kelautan dan Perikanan Provinsi Sumatera Utara dan Kabupaten Batu Bara, pemerintah daerah menyalurkan bantuan tersebut kepada nelayan dalam bentuk alat tangkap ikan (cantrang, trawl, kapal) demi meningkatkan kinerja nelayan dan memproduksi hasil tangkap laut secara maksimal yang pada akhirnya bertujuan meningkatkan kualitas hasil tangkap laut sehingga harga jual hasil tangkap laut mampu bersaing di pasar, baik di TPI (Tempat Pelelangan Ikan) dan sampai pada akhirnya langsung ke tangan konsumen. 
Published July 2018

בd] EKONOMIKAWAN : Jurnal Ilmu Ekonomi dan Studi Pembangunan

ISSN : 1693-7600 (Print), ISSN : 2598-0157 (Online), http://jurnal.umsu.ac.Id/index.php/ekawan

\section{Tabel 1 \\ Banyaknya Alat Penangkap Ikan Menurut Jenisnya tiap Kecamatan di Kabupaten Batu Bara, 2016}

\begin{tabular}{|l|c|c|c|c|c|c|c|}
\hline \multicolumn{1}{|c|}{ Jenis Alat } & $\begin{array}{c}\text { Sei } \\
\text { Balai }\end{array}$ & $\begin{array}{c}\text { Tanjung } \\
\text { Tiram }\end{array}$ & Talawi & $\begin{array}{c}\text { Lima } \\
\text { Puluh }\end{array}$ & $\begin{array}{c}\text { Air } \\
\text { Putih }\end{array}$ & $\begin{array}{c}\text { Sei } \\
\text { Suka }\end{array}$ & $\begin{array}{c}\text { Medang } \\
\text { Deras }\end{array}$ \\
\hline Jaring Angkat & - & 32 & 38 & 38 & - & 22 & 16 \\
\hline Pancing & - & 286 & 173 & 129 & - & 89 & 255 \\
\hline Pukat Kantong & - & 157 & 15 & 42 & - & - & 96 \\
\hline Jaring Insang & - & 324 & 175 & 276 & - & 104 & 257 \\
\hline Perangkap & - & 28 & 28 & 28 & - & 2 & 20 \\
\hline $\begin{array}{l}\text { Alat Pengumpul } \\
\text { Kerang }\end{array}$ & - & 52 & 20 & 15 & - & 28 & 35 \\
\hline $\begin{array}{l}\text { Alat Penangkap } \\
\text { Ikan Lainnya }\end{array}$ & - & 12 & 18 & 15 & - & - & 14 \\
\hline
\end{tabular}

Sumber: BPS Kabupaten Batu Bara, 2017

Jenis alat penangkap ikan yang paling banyak digunakan nelayan pesisir di Kabupaten Batu Bara yaitu pancing dan jaring insang (Batu Bara Dalam Angka, 2017). Sedangkan jenis alat penangkap ikan tersebut paling banyak tersebar dan digunakan oleh nelayan pesisir di kecamatan Tanjung Tiram dan Medang Deras. Diikuti kecamatan Lima Puluh, Talawi dan Sei Suka. Banyaknya jenis alat penangkap ikan yang telah digunakan oleh nelayan yang tersebar menunjukkan bahwa tingginya kebutuhan nelayan akan alat penangkap ikan. Namun karena keterbatasan modal dan sumber daya yang dimiliki nelayan pesisir mempengaruhi produktivitas nelayan pesisir di Kabupaten Batu Bara dan khususnya Desa Pahlawan Kecamatan Tanjung Tiram.

Tolak ukur keberhasilan daripada program pemerintah memberikan bantuan alat tangkap pada nelayan pesisir Desa Pahlawan dapat dilihat dari ada atau tidaknya perbedaan daripada realisasi penerapan bantuan alat tangkap pada nelayan tersebut. Tujuan daripada kebijakan pemerintah memberi bantuan alat tangkap agar nelayan dapat meningkatkan produksi hasil tangkapnya, meningkatkan distribusi pendapatan nelayan yang kemudian menjadi parameter kesejahteraan nelayan pesisir Desa Pahlawan. Namun, semenjak bantuan alat tangkap pada nelayan telah diberikan oleh pemerintah tidak terlihat perubahan yang signifikan terhadap pendapatan nelayan pesisir Desa Pahlawan. Penilaian ini timbul berdasarkan perbedaan produksi hasil tangkap laut antara sebelum dan sesudah adanya bantuan alat tangkap pada nelayan. 
Published July 2018

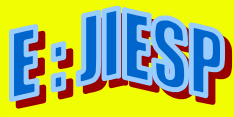

EKONOMIKAWAN : Jurnal Ilmu Ekonomi dan Studi Pembangunan

ISSN : 1693-7600 (Print), ISSN : 2598-0157 (Online), http://jurnal.umsu.ac.ld/index.php/ekawan

\section{KAJIAN TEORI}

Nelayan adalah orang yang bekerja dengan memanfaatkan sumber daya laut perikanan demi penghasilan untuk memenuhi kebutuhan hidupnya sehari-hari. Nelayan pada umumnya tinggal di pinggir pantai yang dekat dengan lokasi kegiatan pekerjaannya.

Kelompok nelayan yang bekerja terdiri dari kelompok nelayan tradisional, yakni yang masih menggunakan alat maupun kendaraan manual sederhana dan kelompok nelayan modern, yakni yang sudah menggunakan alat maupun kendaraan modern.

Kementrian Kelautan dan Perikanan (KKP) dalam upayanya meningkatkan kesejahteraan nelayan dalam negeri dan meningkatkan kualitas hasil tangkap laut Indonesia, melalui Dinas Kelautan dan Perikanan (DKP) masing-masing Kabupaten/Kota telah mencanangkan Program pemberian bantuan kepada nelayan pesisir dalam mendorong produktivitas hasil tangkap lautnya. Bentuk perincian bantuan tersebut dan lain-lain tercantum dalam Petunjuk Teknis Direktorat Jenderal Perikanan Tangkap Tahun 2016. Dan telah tercantum dalam Peraturan Menteri (Permen) Kelautan dan Perikanan No. 8 Tahun 2016.

Berdasarkan keputusan Direktorat Jenderal Perikanan Tangkap (2016) bahwa pemberian bantuan sarana penangkapan ikan diberikan dalam bentuk barang. Barang sebagaimana dimaksud yakni terdiri dari:

1. Kapal penangkap ikan

2. Kapal pengangkut ikan

3. Alat penangkapan ikan

Jumlah produksi atau hasil tangkap nelayan merupakan jumlah seluruh hasil tangkap laut yang didapat nelayan pesisir selama waktu kerja yang kemudian untuk dijual kembali guna mendapat penghasilan demi memenuhi kebutuhan hidupnya. Adapun input yang digunakan adalah mulai dari modal dan biaya produksi hingga tenaga kerja. Sehingga output yang dihasilkan adalah seluruh hasil tangkap laut oleh nelayan pesisir mulai dari ikan, udang, cumi-cumi, kerang dan lain sebagainya.

\section{Hipotesis Penelitian}

Hipotesis dalam penelitian ini adalah terdapat perbedaan rata-rata jumlah produksi/hasil tangkap sebelum dan sesudah Penerapan Bantuan Alat Tangkap pada Nelayan Pesisir di Desa Pahlawan Kecamatan Tanjung Tiram Kabupaten Batu Bara.

\section{METODE}

Penelitian dilakukan di Desa Pahlawan Kecamatan Tanjung Tiram Kabupaten Batu Bara Provinsi Sumatera Utara. Waktu penelitian dilakukan pada tahun 2017. Penelitian ini menggunakan sampel perhitungan Slovin sebanyak 100 orang nelayan pesisir Desa Pahlawan. Dengan menggunakan metode analisis statistik deskriptif non parametrik uji tanda (sign test) dan alat bantu software SPSS (Statistical Package for the Social Science) versi 20.

Menurut Sunyoto (2013) pengujian tanda (sign test) menggunakan data sampel berpasangan dan berkaitan yang berbentuk ordinal berupa tanda positif dan negatif. Dalam uji tanda (sign- test) terbagi atas 2 yakni: Pertama, uji tanda dengan sampel kecil $(<25)$ dan Kedua, uji tanda dengan sampel besar (> 25). 
Dalam penelitian ini menggunakan sampel sebesar 100, dengan demikian peneliti memakai prosedur kedua, uji tanda dengan sampel besar.

Untuk sampel yang besar (>25) dapat dilakukan pengujian Chi Kuadrat, yang rumusnya adalah (Sugiyono, 2012) :

$$
X^{2}=\frac{\left[\left(n_{1}-n_{2}\right)-1\right]^{2}}{n_{1}+n_{2}}
$$

dimana :

$\mathrm{n}_{1}$ : banyak data positif

$\mathrm{n}_{2}$ : banyak data negatif

maka diperoleh hipotesis sebagai berikut (Sunyoto, 2013) :

$\mathrm{H}_{0}: \mathrm{U}_{1}=\mathrm{U}_{2}$ : Rata-Rata dua sampel yang berhubungan adalah sama atau 2 sampel yang berhubungan mempunyai efek perlakuan yang sama.

Ha : $\mathrm{U}_{1} \neq \mathrm{U}_{2}$ : Rata-Rata dua sampel yang berhubungan adalah tidak sama atau 2 sampel yang berhubungan mempunyai efek perlakuan yang tidak sama.

hipotesis di atas dengan kriteria pengujian:

1. Jika Exact. Sig. (2-tailed) $\geq \alpha$; maka $\mathrm{H}_{0}$ diterima dan Ha ditolak.

2. Jika Exact. Sig. (2-tailed) $<\alpha ;$ maka $\mathrm{H}_{0}$ ditolak dan Ha diterima.

\section{Definisi Operasional}

1. Nelayan pesisir adalah penduduk yang bekerja sebagai nelayan daerah pesisir di Desa Pahlawan Kecamatan Tanjung Tiram Kabupaten Batu Bara Provinsi Sumatera Utara.

2. Jumlah produksi/hasil tangkap adalah seluruh jumlah produksi atau hasil tangkap laut yang dihasilkan oleh nelayan pesisir di Desa Pahlawan Kecamatan Tanjung Tiram Kabupaten Batu Bara dalam satuan kilogram per kurun waktu tertentu.

\section{HASIL PENELITIAN DAN PEMBAHASAN}

Adanya penerapan bantuan alat tangkap oleh Dirjen Perikanan Tangkap Kementerian Kelautan dan Perikanan melalui Dinas Kelautan dan Perikanan Kabupaten Batu Bara sejak 2015 dan terealisasi mulai 2016 kepada nelayan pesisir, ini menunjukkan perbedaan sebelum dan sesudah penerapan bantuan alat tangkap dimulai pada variabel jam kerja, jumlah produksi/hasil tangkap dan harga jual. Tahapan analisis data dilakukan dengan uji beda (sign test) pada variabel jumlah produksi/hasil tangkap. Variabel jumlah produksi/hasil tangkap sebelum penerapan bantuan adalah sebagai $\mathrm{X}$ dan sesudah penerapan bantuan adalah sebagai $Y$. 


\section{Tabel 2}

Pengujian Deskriptif Statistik Uji Beda (Sign Test) Variabel Jumlah Produksi/Hasil Tangkap

\begin{tabular}{|l|c|c|}
\hline & $\begin{array}{c}\text { Sebelum Penerapan } \\
\text { Bantuan }(\mathbf{X})\end{array}$ & $\begin{array}{c}\text { Sesudah Penerapan } \\
\text { Bantuan }(\mathbf{Y})\end{array}$ \\
\hline Jumlah data $(\mathrm{N})$ & 100 & 100 \\
\hline Rata-Rata (Mean) & 44,2800 & 48,5300 \\
\hline Standar deviasi & 27,68732 & 31,31284 \\
\hline Maximum & 159,00 & 187,00 \\
\hline Minimum & 12,00 & 12,00 \\
\hline
\end{tabular}

Sumber : data diolah (SPSS v.20;2018)

Rata-rata jumlah produksi/hasil tangkap 100 orang nelayan pesisir sebelum adanya penerapan bantuan adalah sebesar 44,28 kilogram atau 44 kilogram sedangkan sesudah adanya penerapan bantuan adalah sebesar 48,53 atau 49 kilogram. Sebaran data jumlah produksi/hasil tangkap 100 orang nelayan pesisir sebelum penerapan bantuan adalah sebesar 27,69 dan pada sesudah penerapan bantuan adalah sebesar 31,31. Jumlah produksi/hasil tangkap paling banyak dari 100 orang nelayan pesisir sebelum penerapan bantuan alat tangkap adalah 159 kilogram per hari dan sesudah penerapan bantuan alat tangkap adalah 187 kilogram per hari . Jumlah produksi/hasil tangkap paling sedikit dari 100 orang nelayan pesisir di Desa Pahlawan adalah tidak memiliki perbedaan sebelum dan sesudah penerapan bantuan alat tangkap yakni 12 kilogram per hari.

\section{Tabel 3}

Perbandingan Jumlah Produksi/Hasil Tangkap Sebelum dan Sesudah Penerapan Bantuan

\begin{tabular}{|l|c|c|c|}
\hline & $\begin{array}{c}\text { Sebelum Penerapan } \\
\text { Bantuan }(\mathbf{X})\end{array}$ & Tanda & $\begin{array}{c}\text { Sesudah Penerapan } \\
\text { Bantuan (Y) }\end{array}$ \\
\hline & 12,00 & & 12,00 \\
\hline Terendah & 159,00 & $<$ & 187,00 \\
\hline Tertinggi & & $<$ & \\
\hline
\end{tabular}

Sumber : data diolah (SPSS v.20;2017)

Jumlah produksi/hasil tangkap 100 orang nelayan pesisir di Desa Pahlawan memiliki jumlah produksi/hasil tangkap paling sedikit adalah 12 kilogram per hari pada sebelum dan sesudah penerapan bantuan alat tangkap. Dan dengan adanya penerapan bantuan alat tangkap jumlah produksi/hasil tangkap per hari 100 orang nelayan pesisir di Desa Pahlawan menjadi bertambah, sesuai dengan Tabel bahwa jumlah produksi/hasil tangkap per hari nelayan pesisir di Desa Pahlawan sebelum penerapan bantuan adalah lebih kecil daripada sesudah penerapan bantuan alat tangkap. 
Published July 2018

Berdasarkan hasil penelitian bahwa terdapat perbedaan sebelum dan sesudah penerapan bantuan alat tangkap pada jumlah produksi/hasil tangkap nelayan pesisir Desa Pahlawan. Rata-rata secara garis besar jumlah produksi/hasil tangkap nelayan pesisir Desa Pahlawan lebih dari 50 orang nelayan pesisir telah bertambah dengan adanya penerapan bantuan alat tangkap. Diasumsikan bahwa jenis hasil tangkap nelayan pesisir Desa Pahlawan dalam penelitian ini seperti ikan teri, ikan tongkol, ikan dencis, ikan gembung, seafood lainnya seperti kerang dan udang. Dengan kata lain, jumlah produksi/hasil tangkap per hari lebih dari 50 orang nelayan pesisir sebelum penerapan bantuan alat tangkap adalah lebih sedikit dibandingkan dengan sesudah penerapan bantuan alat tangkap, cateris paribus.

\section{Tabel 4}

Frekuensi Sign Test

\begin{tabular}{|c|c|}
\hline \multirow{2}{*}{} & $\begin{array}{c}\text { Sesudah Penerapan Bantuan - Sebelum Penerapan Bantuan } \\
\text { Jumlah Produksi/Hasil Tangkap }\end{array}$ \\
\hline Negative & 8 \\
\hline Positive & 89 \\
\hline Ties & 3 \\
\hline Total & 100 \\
\hline
\end{tabular}

Sumber : data diolah (SPSS v.20;2017)

Tabel di atas menunjukkan nilai frekuensi sign test dari variabel penelitian jumlah produksi/hasil tangkap nelayan pesisir di Desa Pahlawan.

Tabel 5

Uji Statistik Sign Test

\begin{tabular}{|l|c|}
\hline & Sesudah Penerapan Bantuan - Sebelum Penerapan Bantuan \\
\hline & Jumlah Produksi/Hasil Tangkap \\
\hline $\mathrm{Z}$ & $-8,123$ \\
\hline Sig. (2-tailed) & 0,000 \\
\hline \multicolumn{2}{|c|}{$\alpha=0,05$} \\
\hline
\end{tabular}

Sumber : data diolah (SPSS v.20;2017)

Hasil olahan data diketahui bahwa terdapat perbedaan yang signifikan pada jumlah produksi/hasil tangkap nelayan pesisir di Desa Pahlawan antara sebelum dan sesudah penerapan bantuan alat tangkap (Sig. $0,000<\alpha=0,05$ ). Pada umumnya penangkapan ikan lepas pantai yang dilakukan dalam waktu yang lebih lama dan lebih jauh dari daerah sasaran tangkapan ikan mempunyai lebih banyak kemungkinan memperoleh hasil tangkapan (produksi) yang lebih banyak dan tentu memberikan pendapatan yang lebih besar dibandingkan dengan penangkapan ikan dekat pantai (Masyhuri dalam Sujarno, 2008) 
Published July 2018

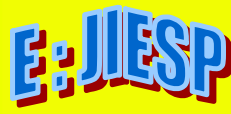

EKONOMIKAWAN : Jurnal Ilmu Ekonomi dan Studi Pembangunan

ISSN : 1693-7600 (Print), ISSN : 2598-0157 (Online), http://jurnal.umsu.ac.Id/index.php/ekawan

Penelitian terdahulu menyatakan bahwa apabila jam kerja yang lebih lama lebih banyak kemungkinan memperoleh hasil tangkapan (produksi). Ini disebabkan adanya nilai efisiensi daripada penggunaan bantuan alat tangkap ikan yang disalurkan pemerintah melalui Dinas Kelautan dan Perikanan Kabupaten Batu Bara.

Realisasi bantuan alat tangkap yang disalurkan oleh pemerintah selama tahun 2017 pada tahun penelitian menunjukkan perbedaan signifikan pada jumlah produksi/hasil tangkap di Desa Pahlawan sehingga apabila terjadi efisiensi penerapan bantuan dari tahun ke tahun ini dapat mempengaruhi angka pendapatan per kapita oleh nelayan pesisir Desa Pahlawan. Angka pendapatan per kapita nelayan pesisir sebagai tolak ukur kesejahteraan masyarakat di Desa Pahlawan kecamatan Tanjung Tiram Kabupaten Batu Bara provinsi Sumatera Utara sehingga ini menjadi keberhasilan program peningkatan kesejahteraan nelayan pesisir oleh pemerintah.

\section{SIMPULAN DAN REKOMENDASI}

Terdapat perbedaan signifikan jumlah produksi/hasil tangkap nelayan pesisir Desa Pahlawan antara sebelum dan sesudah penerapan bantuan alat tangkap. Rata-rata lebih dari 50 orang nelayan pesisir Desa Pahlawan sesudah penerapan bantuan alat tangkap memperoleh hasil tangkapan (produksi) lebih banyak dibandingkan sebelum penerapan banuan alat tangkap. Ini disebabkan adanya nilai efisiensi daripada penggunaan bantuan alat tangkap ikan yang disalurkan pemerintah melalui Dinas Kelautan dan Perikanan Kabupaten Batu Bara.

Adapun yang dapat direkomendasikan kepada pemerintah setempat yakni Dinas terkait Kelautan dan Perikanan Kabupaten Batu Bara agar dapat meningkatkan intensitas penyuluhan ataupun sosialisasi terkait pemberdayaan kelompok masyarakat nelayan pesisir tentang bagaimana meningkatkan produktivitas nelayan pesisir Desa Pahlawan dan DesaDesa lainnya yang berada di lingkungan Kecamatan Tanjung Tiram. Kelompok masyarakat nelayan pesisir masih menunjukkan keterbatasan skill dan wawasan mengenai bagaimana keberlanjutan mata pencaharian melaut dan peningkatan produktivitas dalam jangka waktu yang panjang.

\section{DAFTAR PUSTAKA}

Badan Pusat Statistik. 2017. Kabupaten Batu Bara Dalam Angka 2017. Badan Pusat Statistik Kabupaten Batu Bara. Batu Bara.

Direktorat Jenderal Perikanan Tangkap. 2016. Petunjuk Teknis Bantuan Sarana Penangkapan Ikan di Direktorat Jenderal Perikanan Tangkap Tahun Anggaran 2016. Kementrian Kelautan dan Perikanan. Jakarta.

Kementerian Kelautan dan Perikanan. 2016. Peraturan Menteri Kelautan dan Perikanan No. 8 Tentang Rencana Kerja KKP Tahun 2016. KKP. Jakarta.

Nawawi, Ismail. 2011. Islam dan Bisnis. Penerbit VIV Press. Surabaya.

Prakoso, Jati. 2013. Peranan Tenaga Kerja, Modal dan Teknologi terhadap Peningkatan Pendapatan Masyarakat Nelayan di Desa Asemdoyong Kecamatan Taman Kabupaten Pemalang. Skripsi. Universitas Negeri Semarang : Semarang. 
Rangkuty, Dewi Mahrani. 2018. Dampak Penerapan Bantuan Alat Tangkap pada Nelayan Pesisir di Desa Pahlawan Kecamatan Tanjung Tiram Kabupaten Batu Bara. Jurnal Ilmiah. Jurnal Jepa Vol. III No. 1 Januari 2018. Universitas Pembangunan Panca Budi. Medan.

Sugiyono. 2012. Metode Penelitian Bisnis. Penerbit Alfabeta . Bandung.

Sunyoto, Danang. 2013. Analisis Data Ekonomi dengan Menggunakan SPSS. Penerbit Indeks . Jakarta. 